Article

\title{
Islam and Roman Catholicism as Transnational Political Phenomena: Notes for a Comparative Research Agenda
}

\author{
Ted G. Jelen * and Mehran Tamadonfar \\ Department of Political Science, University of Nevada, Las Vegas, 4505 Maryland Parkway, \\ Las Vegas, NV 89154-5029, USA
}

* Author to whom correspondence should be address; E-Mail: jelent@ unlv.nevada.edu.

Received: 9 August 2011; in revised form: 19 September 2011 / Accepted: 29 September 2011 / Published: 30 September 2011

\begin{abstract}
In this paper, we offer some preliminary insights into a comparison of Islam and Roman Catholicism as transnational or "transcivilizational" political phenomena. We note that both traditions are monotheistic, offer universalist theologies, and have played important political roles both historically and in contemporary national and international politics. The comparison provides some additional insights into the role of 'the sacred' in politics at various levels, and presents the possibility of an intermediate level of analysis in comparative politics.
\end{abstract}

Keywords: Islam; Catholicism; comparative politics; church-state relations

\section{Introduction}

Our purpose in this paper is to offer some preliminary insights into a comparison of Islam and Roman Catholicism as transnational (or, in Huntingtonian terms, transcivilizational) political phenomena. We are hopeful that such a systematic comparison would be intellectually fruitful, and would have two preliminary rewarding payoffs. First, such a research program would offer an intermediate alternative to what might be termed the "level of analysis" problem in comparative politics. That is, systematic study of the different national and regional manifestations of religious traditions with clearly identified spiritual and intellectual roots might well provide insights unavailable with either large $\mathrm{N}$ comparative studies or analyses of religious politics in the context of a single national or geographical setting. Second, such focused international comparisons would facilitate the 
integration of religion into more mainstream analyses of national and regional politics. Although political scientists have paid greater attention to religion as a political variable in recent decades than in previous eras, religious politics remains something of a specialized subfield in political science.

We begin by noting the political importance of religion. Today, few analysts of comparative politics would dispute that religion is often a central focus in national and international politics. Although many analysts had earlier suggested that religious politics simply constituted vestiges of pre-modern systems $[1,2]$ it cannot be gainsaid that religion is of vital importance in contemporary political life. Whether one is concerned with the Palestinian-Israeli conflict, ongoing religio-political conflict in Lebanon, sectarian violence in Iraq, political cleavages in Northern Ireland or Afghanistan, and the contemporary desert politics of the Sudan, or the Christian Right in the United States, the fact that religion is the center of many contemporary national political cleavages and international politics conflicts appears to be beyond controversy. Even in supposedly "secular" settings, such as Western Europe or the People's Republic of China, the highly visible presence of Muslims (and their descendants) or the assertiveness of Falung Gong, respectively, attest to the political importance of religion in a variety of settings.

Of course, one of the important questions posed by the present study is whether religious belief or practice merits the status of a genuine independent variable (a la Max Weber in The Protestant Ethic and the Spirit of Capitalism) or whether the public assertion of religion is merely epiphenomenal as many recent and contemporary Marxists (among others) would have it. That is, is politically assertive religion a cause, or effect, of other political phenomena? It is our hope that the systematic comparative study of specific religious traditions can shed light on this fundamental issue.

With respect to the "level of analysis" issue in comparative politics, it seems clear that there is no consensus on the appropriate manner in which to study systems outside those inhabited by the observer. For analysts who might be termed "comparativists," cross-national comparisons are not typically considered problematic. Indeed, the existence of such broad research endeavors as the World Values Surveys, or the Eurobarometer (or Afrobarometer) studies, suggest that many observers continue to find such efforts quite promising. Further, it is not difficult to find recent and contemporary scholarship which provides such cross-national analyses. Indeed, Phillip Converse's elegant “of Time and Partisan Stability" [3] held out the possibility of genuine cross-national laws several decades ago. More recent efforts would include the earlier work of Francis Fukayama [4]: in which Fukayama suggested that cultural differences across the globe were giving way to the dominance (indeed, the triumph) of liberal western, democratic values. Indeed, it could be argued that such a perspective, although not particularly common in the contemporary study of comparative politics, was the basic premise of earlier accounts of developmentalism, as well as its limitations.

Nor are such distinctions only important to scholars. Indeed, much of the rhetoric of the administration of George W. Bush assumed the universality (and universal desirability) of such Western concepts as freedom and democracy, as well as the assumption that most people in most cultures would share a common understanding of these terms. An important assumption surrounding the "neoconservative" movement is that there exist universal human values, which are generally best exemplified by the United States, or by the "West."

Some scholarly analyses of religious politics have also sought to discover valid cross-national generalizations. In their recent, ambitious (and perhaps audacious) study, Sacred and Secular: Religion 
and Politics Worldwide [5], Pippa Norris and Ronald Inglehart have suggested that the extent of religious belief and practice in particular cultural settings can largely be explained by the presence or absence of "insecurity." That is, people living in situations in which they are threatened by economic deprivation, national disasters, or militarily powerful neighbors are more likely to embrace beliefs in the supernatural than are their more securely situated counterparts. This controversial thesis, which is supported by resourceful analyses of a variety of data sources, supports the possibility that religious belief (and its political consequences) in diverse contexts is rooted in common, and perhaps universal, human characteristics.

Similarly, rational choice models of "supply-side" religious behavior have extended the idea that religion is a human universal, based on common human needs and desires, and that variations in religious belief and practice can be attributed to differences in the availability or "supply" of religious alternatives [6,7]. Indeed, in this research tradition, which is rooted in economic theory, Stark and Finke have suggested that the "demand" for "religious goods" is constant across societies, and that differences in people's access to different religious traditions account for differences in the extent and intensity of religious activity [8]. Further, they hypothesize that the consequence of religious belief and practice are affected by religious diversity has been supported in the United States [9] and in Western Europe [10].

Further, the decade of the 1990s witnessed the multivolume "Fundamentalism Project," conducted by Martin Marty and R. Scott Appleby, and published by the University of Chicago Press. Here, the project was undertaken with the aspiration of discerning a common meaning to the term (and phenomenon) of religious "fundamentalism" [11-15]. While many other authors demurred on the concept of fundamentalism, and offered distinctions between other "fundamentalisms" and the specific faith each author sought to examine, the project assumed at a minimum, a "family resemblance" among different doctrinally and conservative religious traditions.

Thus, the idea that comparisons across nations, regions, or "civilizations" are possible, and possibly fruitful, is a common one, which is invoked frequently by political scientists and practitioners alike. Of course, this generally "comparativist" approach is not without its critics. It is often suggested that facile comparisons across diverse cultural or political systems assume the answers to the most interesting questions, and deemphasize the most important differences among political systems in different settings. A generation ago, Alistair Macintyre offered a scathing indictment of what we have termed the "comparativist" approach to the study of comparative politics in the 1970s [16].

A contrasting style of the study of comparative politics might be termed the "area studies" approach, in which analysts immerse themselves in the culture and politics of a particular nation or region. Such analysts seek "subjectively adequate" descriptions and explanations of political phenomena, which are intelligible to the persons whose actions are being described and analyzed. Of course, this is not to say that comparisons across political or cultural settings are not possible; however, the area studies approach is generally inductive, with cross-national similarities to be discovered, rather than assumed a priori [16].

Recent examples of this approach can be found in the work of Samuel Huntington. In his seminal, and controversial work, The Clash of Civilizations, Huntington divides the world into a number of "civilizations," defined geographically, culturally, and (especially) religiously [17]. Huntington suggests that cooperative interaction between or among civilizations is quite difficult, and may often 
be impossible, owing to profound differences in the moral and ethical sensibilities among diverse civilizational settings. For example, Huntington has suggested that the admission of Turkey to the EU is improbable, and perhaps ill-advised, since Turkey is representative of a "Muslim" civilization, with important differences with the civilization which comprises Western Europe.

Our aspiration here is to suggest that comparisons among nations with Catholic or Muslim populations, or in which Catholics or Muslims are a politically relevant minority, provides a promising, if necessarily incomplete, basis for political analysis at a level between the comparativist and area studies approaches. The politics of liberation theology in Brazil and the politics of postCommunist Poland were (and remain) quite different, despite the fact that politically consequential actors in both settings rely on a common (and self-consciously universal) Catholic heritage. Similarly, despite the fact that there are substantial and important differences in the politics of Nigeria, Iran, and Indonesia, the fact of a common Muslim heritage in these national settings provide an intriguing basis of comparisons for politics in these nations. The shared understanding of the importance of the Qur'an, the Sunna and Hadith, the common reliance on the Shar'ia in the followers' daily lives and the legal systems, and (despite sectarian differences) the common commitment to the ideals of social justice and fairness, suggest the possibility of a common set of issues, understandings, and controversies. Similarly, comparisons between Catholicism and Islam seem promising, in light of certain theological and political features common to both faith traditions, to be detailed in the following section.

Of course, the existence and importance of such similarities are ultimately empirical questions. Comparisons are not "true" or "false" in any conclusive sense, but are merely more or less useful. We are persuaded that a comparison between Catholicism and Islam is likely to be fruitful, and is potentially more promising than a comparison between Islam and (say) a more general account of Christianity.

To some extent, the Reformation institutionalized schism within Christianity. That is, the rise of Protestantism begun by Martin Luther has presented Christian cultures with a fact of pluralism with which all Christians must contend. Arguably, the existence of plural faith traditions within Christianity has limited the potential political power of Christian denominations, and may have imposed an individualist bias in Christian politics. Put simply, the fact that the Catholic Church is no longer able to dominate political life in any nation means that the Church must function as one interest group among many $[18,19]$. In some instances, this may lead to a focus on individual salvation as opposed to the development of more communal political responses. Politically, the diversity of Christianity was largely institutionalized by the Treaty of Westphalia of 1648.

Sectarian schism in Islam, which began with Muhammad's death, was rooted in political disputes over temporal authority in the Muslim community [20]. By relying on the Quran, Hadith (Muhammad's sayings), and Sunnah (Muhammad's practices), the Sunnis favored a democratic approach to communal affairs and favored the use of communal consultation (Shura), consensus (Ijma), and oath of allegiance (Bay'ah) in the choice of the political authority. The minority, the Shi'ites, opted for a legitimist approach and by advancing the doctrine of Vassayah (designation) acknowledged Muhammad's appointive rights and followed Ali, whom they claimed to have been designated by Muhammad as his successor. Over the centuries, sectarian and factional differences became more complicated involving theological as well as political disputes over such issues as the 
nature, scope, and line of authority. Despite these sectarian, scholastic, and factional divisions, contrary to Christianity, in Islam there has never been a meaningful commitment to pluralism and tolerance. As evidence by the current sectarian violence in Iraq, Pakistan, and Lebanon, Muslims have never overcome their early violent conflicts and continue their sectarian claims to their monopoly over the right path.

\section{Islamic-Catholic Similarities}

The prospect of ambitious comparisons between Muslim and Catholic political actors suggests that there exist important similarities between the two traditions. Indeed, it is possible to identify a number of important points of comparison between Roman Catholicism and contemporary Islam.

First, both traditions are monotheistic. Arguably, this is a politically important characteristic, since monotheism implies the very possibility of universality. For Muslims, Islam is both universal and central in the sense that it is the primary source of identification. If one were to make a theological case for the comparativist approach, one might begin by suggesting that, if there is indeed only one God, it may be unlikely that the deity would create radically different versions of humanity or human society. On a more temporal scale, the universal potential of monotheism has important political implications. Both Islam and Catholicism have active histories of missionary activity. The term "Catholic" means "universal", and the Catholic Church has historically been an active moral agent in European colonialism [21-23]. Indeed, it has been suggested that the center of gravity of the Catholic Church has moved south toward the less developed world, and that a majority of the world's Roman Catholics no longer inhabit Europe or North America.

In Islam, the oneness of God is also reflected in the oneness and the primacy of the community. The expansion of Islam was largely justified and explained by communal needs and interests, similar to Catholicism. The history of Islam suggests that Muslims have been quite active in spreading the faith outward from its Arab (and semitic) roots. This expansion began with Muhammad and continued throughout the history of Islam. The adoption of Shi'ism by the Persian monarchs at the beginning of the $16^{\text {th }}$ century; and the Muslim armies' victories in Asia, the Middle East proper, and Europe in the succeeding centuries resulted in a massive Islamic empire. Even after the end of the Ottomans and the subsequent political decline of Islam, today the nations in which Muslims constitute a majority or a politically consequential minority (such as India) stretch from Morocco to Indonesia.

Monotheism entails another politically important implication as well. The injunction in the First Commandment to "have no other Gods before me" can create or exacerbate political tension, by making religious syncretism or pluralism extremely problematic [24,25]. That is, the exclusivity demanded by the great monotheisms of Judaism, Christianity, and Islam render the sort of melding and coexistence which characterize Buddhism and Confucianism in Viet Nam [26], or Buddhism and Shinto in Japan [27] extremely problematic. In turn, this type of religious particularism can make the accommodation and compromise which comprise some notions of democratic civility most difficult. Thus, religious politics, as a setting in which Muslims and Catholics are salient participants, is likely to be relatively intense, because the politics of monotheism is likely to resemble certain features of a zero-sum game. 
Second, it is perhaps no accident that the term "fundamentalism" seems most appropriately applied to doctrinally conservative variants of Christianity and Islam. Both Catholics (along with other Christians) and Muslims are "people of the book," who derive their central theological insights and values from sacred texts. The existence of the Bible and the Qu'ran allows for the possibility of theological and perhaps political renewal, since it is possible for adherents of Christianity and Islam to return to the spiritual roots (or "fundamentals") of the faith traditions. Politically active Muslims and Christians have resources from which to criticize the actions of both secular and religious political leaders.

Further, both Catholic and Islamic politics are animated by questions concerning the manner in which the core religious texts are supplemented. Neither the Qu'ran nor the Bible contain specific answers to all contemporary problems, and interpretation is therefore necessary. For Catholics, Aquinian notions of natural law, combined with the authority of the Papacy, provide theological, organizational, and intellectual resources by which current social and political issues can be analyzed and debated. Despite the claims of authority of the Holy See, the Catholic Church regards itself as primarily a teaching institution, in which the well-formed individual conscience is the final authority [28,29]. Indeed, the Second Vatican Council has drawn attention to the methodology of Catholic theology and policy making [30,31].

With respect to Islam, the sectarian, scholastic, and factional controversies involve questions of the authority of the Hadith, the Sunna, and Ravayah (sayings and traditions of the Shi'a imams). These divisions within Islam involve different groups of Muslims, but also theological questions of how the Qu'ran is to be interpreted (and perhaps supplemented), and how religious and political policy is to be made. Sectarian schisms in Islam were not initially rooted in theological disputes over the authority of the Qu'ran and Muhammad's Traditions (Sunna and Hadith). The division between the Sunni and Shi'a Muslims was simply over the nature of political authority. Major theological disputes emerged over time as various factions within which each sect followed different sources and developed distinct traditions. Underscoring the original intent and questioning non-Quranic sources, some rejected any reinterpretation as Bida'ah (innovation) and rejected ijithad (independent judgment) as an unacceptable mechanism in search of Islamic principles. Others, especially the Shi'a clerics, took the position that it is the function of the clerical establishment to rely on independent judgment in search of the Islamic values and instructions.

Third, a cursory examination of the politics of Islam and Catholicism suggests that adherents of both faith traditions have behaved similarly when situated in comparable political and theological contexts. Both traditions have been located in situations in which the respective faith tradition is locally dominant. That is, there exist settings in which Catholicism and Islam (indeed, a particular variant of Islam) lack serious religious competitors. Examples might include contemporary Iran, with a strong Shi'i majority, as well as contemporary Poland, or the Iberian nations of Spain and Portugal, and some nations of Latin America. In both instances, the possibility exists that the dominant religious tradition could provide a "sacred canopy" [32] or a set of shared values within which social and political life is conducted. However, recent research has suggested that the sacred canopy model may not be viable in the era of globalization [22]. Rather, the consequences of religious monopoly in Iran and in Poland, and elsewhere, seem to exemplify the "lazy monopoly" [8] in which religious belief and practice may decline as the result of a lack of competition among different faith traditions. 
As we have suggested elsewhere, both Islam and Catholicism have served as sources of prophetic opposition to hostile or repressive regimes. To continue with the examples of Iran and Poland, it is difficult to imagine serious accounts of the fall of the Shah or the fall of Polish Communism, without assigning primary credit to Ayatollah Khomeini or Pope Paul John Paul II, respectively [18]. We do not, of course, wish to exaggerate the similarities between post-Communist Poland and postrevolutionary Iran. Poland is a multiparty parliamentary democracy, while Iran is an official theocracy, with institutions and values inimical to many principles taken for granted in the West. Rather, our point is much more limited. In both nations, religious leaders and religious values were essential to the achievement of regime change. Following regime change in both settings, religion (understood both institutionally and behaviorally) became far less socially and politically consequential.

While it is correct to suggest that the Iranian revolution was the product of collective efforts on the part of many forces with divergent interests and goals, it is hard to exaggerate Khomeini's role in the success of the revolutionary process and the establishment of an Islamic system. Khomeini played a pivotal role in the mobilization of the masses, provided for a focused revolutionary strategy, and marginalized the non-Islamist revolutionaries in the establishment of the post-revolutionary regime. To the extent that these cases provide material for a general model of prophetic religious politics, it seems that religious values might be most politically consequential in hostile environments. In such settings, religion may be the amphetamine, rather than the opiate, of the masses.

Another setting in which Catholicism and Islam have had similar consequences is in religious environments in which the respective faith tradition is one of a small number of serious religious competitors. Example of such settings might include analyses of the role of Islam in the politics of the Indian subcontinent, the conflict between Shi'ites and Sunnis in contemporary Iraq, the politics of Palestine and Israel, and the religious politics of Northern Ireland. In such cases, people acting under the banner of Islam (or a variant thereof) or Catholicism have acted as serious competitors for political power, and have not always confined their participation to democratic or nonviolent activities. A question for future research is whether such intense religious conflict is a function of the structure of a bipolar religious market, the nature of the religious traditions in question, or both.

Finally, there exist settings in which Muslims and Catholics constitute small, but visible minorities. Examples of this type of context might include the presence of Muslims in Western Europe or the United States [33] or Roman Catholics in the People's Republic of China, certain nations of Africa, or the United States in the 19th century [25]. In these instances, adherents of Islam or Catholicism largely bear the stigma of immigrants, and are frequently the victims of legal and social discrimination. Religious minorities outside the "home" civilization of the respective faith tradition may often be accused of divided loyalties, and may be denied political or legal equality, regardless of their citizenship status. This is particularly evident in the treatment of Muslims in Europe and the United States in the post-September 11 era. The French ban of the Islamic hijab from schools, and the recent initiatives on the part of British authorities to marginalize Muslim women who insist on wearing Islamic hijab are some of the examples of legal, social and political initiatives that are considered discriminatory. Indeed, the first several years of the 21 st century have witnessed a decline in tolerance for Muslims in several nations of Western Europe [34-35] and the United States. The recent Congressional hearings on the political attitudes and loyalties of Muslim communities in the United States spearheaded by Congressman Peter King, and the legislative initiatives designed to ban the use 
of the Shari'ah in adjudication in the American courts are some of the examples of the increasing intolerance towards Muslims and Islam in the United States. To date, more than a dozen states have considered or adopted measures to restrict judges from consulting Islamic or foreign laws in their decision-making process. A number of the 2012 Republican Presidential candidates, elected officials, and activists continue to mobilize the public against what they describe as the "menace of Islamic Law in the United States" and its totalitarian proclivities [36]. Similarly, the loyalty of American Catholics has been challenged as recently as 1960, and was an issue in the remarkably narrow victory of John F. Kennedy in the Presidential election of that year [25].

\section{Islamic-Catholic Differences}

Of course, there exist important differences between the faith traditions of Islam and Roman Catholicism, which might well render comparisons between the two religions difficult or problematic. Differences in organizational structure, theology, and political context complicate any straightforward attempt to produce unambiguous generalizations about religious politics.

Perhaps the most important political distinction between Catholicism and Islam is that Catholicism is far more institutionally developed and defined than Islam. The Holy See is a sovereign nation-state, with most of the attendant prerogatives and responsibilities [28]. The Vatican has negotiated its internal status with several other nation-states, including a Concordat with Poland in the mid-1990s [37]. More generally, the Church has a complex structure of dioceses and parish, each with seminaries, monasteries, schools, and other institutions. All of these institutions operate within the context of national politics in different nation-states, and the Church must negotiate its status in each of these. In some instances, such as Poland, the status of the Church may be determined via diplomatic relations between the host nation and the Vatican. In others, such as the United States, the Church must operate within the more general national legal structures. In still others, such as Mexico, church-state relations may be colored by informal agreements between national churches and the government of a particular nation.

The fact that the Church has institutional interests to protect may lead Catholic elites to compromise the Church's political role in other areas. For example, under the Communist regime in post World War II Poland, the Church was largely silent on matters such as international alliances or abortion, in order to protect its churches, seminaries, and universities [38]. Similarly, in the United States, the Church was a vocal opponent of organized prayer in public schools, since such prayers were thought to have Protestant bias, and to threaten the faith commitments of Catholic students in institutions of public education [39].

By contrast, comparable transnational organization in Islam does not appear to exist. In view of the fact that Islam rejects mediation between Humanity and God, Muslims have never been committed to establishing an extensive organizational infrastructure similar to the Catholic Church. The Sunnis generally reject the type of clericalism that is dominant in Shi'ism for its inconsistency with the Islamic worldview. The clerical establishment in Shi'ism lacks a hierarchical structure and the authority of individual clerics derives from the size of their followers, their scholastic contribution, and their perceived personal piety. Of course, Khomeini and his followers equated Islam with clericalism 
and favor a hierarchical clerical establishment. However, many Shi' ites do not subscribe to such ideas and, at best, favor an informal and nonhierarchical clerical establishment.

In contemporary Muslim societies, with the clear exception of Iran, the ever-present conflict between the religious establishment and the secular political authorities prevents the emergence and consolidation of the power of a centralized and authoritative transnational religious establishment. While many Muslim states have experimented with integration, mainly in reaction to external threats, these experiments have failed due to divergent State interests. More importantly, given the secular nature of these states and the fear of the religious elements, there has been very little effort in encouraging religiously-based integration. The creation of the Arab League was largely based on ethno-linguistic commonality of its members. Sponsored by the secular Arab states, this league lacks support of the religious establishments and religious legitimacy. Today, the Organization of Islamic States is the primary transnational organization that aims at furthering the interests of the Muslim countries through collective action. It is no surprise, however, that this organization also lacks the necessary credibility, largely due to its subservience to the state (largely secular) authorities, who intend to marginalize the Islamist elements in these societies.

Further, the faith traditions differ in terms of their roles in global politics. For centuries, the Catholic Church has operated near the center of international politics, and has a history of being an influential international actor in its own right. During the period in which the European powers were the dominant actor in international relations (including European imperialism), the Church has provided resources, rationales, and legitimacy for states and empires.

In contemporary world politics, of course, the role of the Church remains important, but the Church's influence has declined. The secularization of Europe, and the fact that Catholics remain a religious minority in the United States, has reduced the political role of the Church to one in which moral suasion is of primary importance [39]. Although Pope Benedict XVI has tried to emphasize the Christian character of Europe and of Western civilization generally, the political influence of the Church is limited, and of course, varies across nation states. As time passes, it will be interesting to observe relations between the Vatican and the EU, or relations between the EU and various national Churches. Further, the idea that Poland can occasion the return of Europe to its Christian, and specifically Catholic, roots is a powerful one in that country, but one which seems unlikely to transform the nature of European society.

During the early part of the 20th century, the Muslim world witnessed the end of colonialism and the demise of numerous monarchic systems. Many of the emerging regimes in Egypt, Iraq, Syria, and a number of other Muslim countries increasingly embraced secular western ideologies and implemented policies that often diverged significantly from the ancient regimes and the Islamic traditional practices. In some states, this trend resulted in violent confrontations between the state and religious forces which generally culminated in repressive measure that marginalized and alienated the religious establishments. Given the enormity of the social, economic, and political difficulties facing these regimes, many failed to accommodate popular demands. Domestic failures were compounded by these regimes' external problems at the regional and global levels. The intra-Arab conflicts, especially conservative-radical regime rivalries, Arab-Israeli imbroglio, and the politics of oil preoccupied the Muslim states for a good part of the 20th century. 
By the middle of the 20th century, global interest in the Middle Eastern oil offered new opportunities and caused great difficulties for the major producers and exporters of oil. The West's increasing dependence on oil and their commitment to ensure the security of oil resources resulted in foreign political influences and made many Muslim states increasingly dependent on the West. This dependency along with the western commitment to Israel, which largely disregarded the demands and expectations of the Muslims, intensified internal resentments and frictions and jeopardized the legitimacy of the secular states. The current "Arab Awakening" is a vocal response by the "Arab street" that is frustrated with the secular and irresponsive political authorities in countries like Egypt, Tunisia, Libya, Yemen, Bahrain, among others.

The success of the Iranian revolution and the rise of the Islamist movements opened a new chapter in the relationship between the State and religious forces in most Muslim societies. To the Muslim masses, the failures of the past century were the consequence of the marginalization of Islam in the politics of their states and the adoption of liberal democratic or socialist ideologies and policies. The theocratic regime in Iran gradually became the rallying point for the disenfranchised and deprived Muslims who had never benefited from experiments with modernism in many Arab countries. The Islamist forces challenged the existing political authorities in Afghanistan, Algeria, Jordan, Lebanon, and a host of other Muslim countries. With Western support, the Islamists defeated the Soviets and established an Islamist regime in Afghanistan. In many other Muslim countries including Jordan, Algeria, the occupied territories, and Lebanon, the Islamists established and asserted their new political role through electoral success. Even though these successes in Jordan and Algeria were short-lived, the Iranian success continued to hold promises for other Muslims in western-oriented states of the Middle East.

The events of September 11, 2001 brought the Muslim grievances against their leaders and the West to the forefront of global politics. Furthermore, the West became aware of the potential regional and global threats of the Islamist movements. Western failures in Afghanistan, ongoing conflicts with Iran over its nuclear ambitions, the Israeli attack on Lebanon in the summer of 2006, disregard for the plight of the Palestinians, the invasion of Iraq, and continued support for conservative pro-Western Arabs have convinced many Muslims that the West is truly uninterested in addressing the problems of the Muslim world. In fact, to many, these policies are indicative of the Western rejection of Islam and its political relevance in the Muslim world. Many Muslims are convinced that the West, and particularly the United States, is intent on the destruction of Islam and the continued subjugation of Muslims. While expressing a commitment to democratic change in Iraq, the United States openly undermines the democratically elected Hamas government in the occupied territories; continues to disregard repressive measures by the Saudi, Egyptian, and Jordanian regimes; and turns a blind eye to the anti-revolutionary measures in Bahrain and Yemen orchestrated by the U.S. allies. In light of the greater Arab awareness and rising expectations, any long-term successful policy towards the Muslim world must take note of the long-held grievances and domestic and regional problems.

\section{Conclusions}

In this exploratory essay, we have attempted to suggest some promising avenues of research to be found in systematic comparisons of Islam and Roman Catholicism. Again, we anticipate two general 
payoffs: A partial solution to the level of analysis problem in the study of comparative politics, and the hope for mid-level generalizations about the political roles of religion among practitioners of two of the world's great monotheisms.

Given the similarities between the two faith traditions, we hypothesize that the political role played by Islam and Catholicism in a given setting is largely determined by two variables: the nature of the religious "market" within a particular region or nation-state, and the role of that nation-state in regional or global politics or economics. While we maintain that religion is a genuinely independent variable, and is not simply epiphenomenal, the presentation of religious ideas and actors in the public sector seems contingent on the internal and external circumstances in which religion may or may not assume a political role. We are hopeful that this preliminary essay provides the basis for a public intellectual conversation well-begun.

\section{References}

1. Almond, G.; Coleman, J. The Politics of the Developing Areas; Princeton University Press: Princeton, NJ, USA, 1961.

2. Pye, L.W.; Verba, S. Political Culture and Political Development; Princeton University Press: Princeton, NJ, USA, 1965.

3. Converse, P.E. Of Time and Partisan Stability. Comp. Polit. Stud. 1969, 2, 139-172.

4. Fukayama, F. The End of History and the Last Man, reprint edition; Harper Perennial: San Francisco, CA, USA, 1993.

5. Norris, P.; Inglehart, R. Sacred and Secular: Religion and Politics Worldwide; Cambridge University Press; New York, NY, USA, 2004.

6. Finke, R.; Stark, R. The Churching of America: 1776-1990; Rutgers University Press: New Brunswick, NJ, USA, 1992.

7. Iannaccone, L.R. The Consequences of Religious Market Structure. Ration. Soc. 1991, 3, 156-177.

8. Stark, R.; Finke R. Acts of Faith: Explaining the Human Side of Religion; University of California Press: Berkeley, CA, USA, 2000.

9. Cook, E.; Jelen, T.G.; Wilcox, C. Catholicism and Abortion Attitudes in American States: A Contextual Analysis. JSSR 1993, 32, 223-230.

10. Jelen, T.G.; Wilcox, C. Context and Conscience: The Catholic Church as an Agent of Political Socialization in Western Europe. JSSR 1997, 37, 28-40.

11. Marty, M., Appleby, R.S., Eds. Fundamentalisms Observed; University of Chicago Press: Chicago, IL, USA, 1994.

12. Marty, M., Appleby R.S., Eds. Fundamentalisms and the State; University of Chicago Press: Chicago, IL, USA, 1996.

13. Marty, M., Appleby, R.S., Eds. Fundamentalisms and Society; University of Chicago Press: Chicago, IL, USA, 1997.

14. Marty, M., Appleby, R.S., Eds. Fundamentalisms Comprehended, New Edition; University of Chicago Press: Chicago, IL, USA, 2004. 
15. Marty, M., Appleby, R.S., Eds. Accounting for Fundamentalisms; University of Chicago Press: Chicago, IL, USA. 2004

16. MacIntyre, A. Is a Science of Comparative Politics Possible? In Against the Self-Images of the Age; MacIntyre, A., Ed.; University of Notre Dame Press: South Bend, IN, USA, 1989; pp. 260-279.

17. Huntington, S.P. The Clash of Civilizations and the Remaking of the World Order; Simon and Schuester: New York, NY, USA, 1996.

18. Tamadonfar, M.; Jelen T.G. Religion, Regime Transformation, and the Routinization of Charisma: Iran and Poland, Presented at the Annual meeting of the Southern Political Science Association, New Orleans, USA, January 2006.

19. Byrnes, T.A. The Challenge of Pluralism: The Catholic Church in Democratic Poland. In Religion and Politics in Comparative Perspective: The One, the Few, and the Many; Jelen, T.G., Wilcox, C., Eds.; Cambridge University Press: New York, NY, USA, 2002; pp.27-44.

20. Tamadonfar, M. The Islamic Polity and Political Leadership: Fundamentalism, Sectarianism, and Pragmatism; Westview Press: Boulder, CO, USA, 1989; p. 61.

21. Lyon, A.J. The East Timorese Church: From Oppression to Liberation. In The Catholic Church and the Nation-State: Comparative Perspectives; Manuel, P.C., Reardon, L.C., Wilcox, C., Eds.; Georgetown University Press: Washington, DC, USA, 2006; pp.131-148.

22. Rutagambwa, E. The Rwandan Church: The Challenge of Reconciliation. In The Catholic Church and the Nation-State: Comparative Perspectives; Manuel, P.C., Reardon, L.C., Wilcox, C., Eds.; Georgetown University Press: Washington, DC, USA, 2006; pp.173-190.

23. Heywood, L. The Angolan Church: The Prophetic Tradition, Politics, and the State, In The Catholic Church and the Nation-State: Comparative Perspectives; Manuel, P.C., Reardon, L.C., Wilcox, C. Eds.; Georgetown University Press: Washington, DC, USA, 2006; pp.191-206.

24. Kurtz, L. Gods in the Global Village: The World's Religions in Sociological Perspective; Pine Forge Press: Thousand Oaks, CA, USA. 1995.

25. Jelen, T.G.; Wilcox, C. The Political Roles of Religion. In Religion and Politics in Comparative Perspective: The One, the Few, and the Many; Jelen, T.G., Wilcox, C., Eds.; Cambridge University Press: New York, NY, USA, 2002; pp.314-324.

26. Fitzgerald, F. Fire in the Lake: The Vietnamese and Americans in Viet Nam; Little Brown: Boston, MA, USA, 1972.

27. Toyoda, M., Tanaka, A. Religion and Politics in Japan, In Religion and Politics in Comparative Perspective: The One, the Few, and the Many; Jelen, T.G., Wilcox, C., Eds.; Cambridge University Press: New York, NY, USA, 2002; pp. 269-286.

28. Jelen, T.G. The American Church: Of Being Catholic and American. In The Catholic Church and the Nation-State: Comparative Perspectives; Manuel, P.C., Reardon, L.C., Wilcox, C., Eds.; Georgetown University Press: Washington, DC, USA, 2002; pp. 69-88.

29. Dillon, M. Cultural Differences in the Abortion Discourse of the Catholic Church: Evidence from Four Countries. Soc. Relig. 1996, 57, 25-36.

30. Himes, K.R. Vatican II and Contemporary Politics. In The Catholic Church and the Nation-State: Comparative Perspectives; Manuel, P.C., Reardon, L.C., Wilcox, C., Eds.; Georgetown University Press; Washington, DC, USA, 2006; pp. 15-32. 
31. Ferrari, L.L. The Vatican as a Transitional Actor. In The Catholic Church and the Nation-State: Comparative Perspectives; Manuel, P.C., Reardon, L.C., Wilcox, C., Eds.; Georgetown University Press: Washington, DC, USA, 2006; pp. 33-50.

32. Berger, P. The Sacred Canopy: Elements of a Sociological Theory of Religion; Anchor: Garden City, NY, USA, 1969.

33. Fetzer, J.S.; Soper, J.C. Muslims and the State in Britain, France, and Germany; Cambridge University Press: New York, NY, USA, 2004.

34. State Multiculturalism has Failed, Says David Cameron, BBC News, February 5, 2011. Available online: http://www.bbc.co.uk/news/uk-politics-12371995?print=true (Accessed on 9 February 2011).

35. Clark, M., Germany's Angela Merkel: Multiculturalism Has 'Utterly Failed,' Christian Science Monitor October 17, 2010. Available online: http://www.csmonitor.com/layout/set/print/content/ view/pr (Accessed on 9 February 2011).

36. Elliot, A. What's Behind Nationwide Anti-Shariah Push? New York Times, reprinted on msnbc.com (Accessed on 31 July 2011).

37. Byrnes, T.A. The Polish Church: Catholic Hierarchy and Polish Politics. In The Catholic Church and the Nation-State: Comparative Perspective; Manuel, P.C., Reardon, L.C., Wilcox, C., Eds.; Georgetown University Press: Washington, DC, USA, 2006; pp. 103-116.

38. Delfattore, J. The Fourth R; Yale University Press: New Haven, CT, USA, 2004.

39. Burns, G. The Frontiers of Catholicism: The Politics of Ideology in a Liberal World; University of California Press: Berkeley, CA, USA, 1992.

(C) 2011 by the authors; licensee MDPI, Basel, Switzerland. This article is an open access article distributed under the terms and conditions of the Creative Commons Attribution license (http://creativecommons.org/licenses/by/3.0/). 